premature peripheral vascular disease - that necessitated a hospital stay of more than 30 days they took nearly as long as the elderly (aged 70 and over) to recover sufficiently to leave hospital (mean 50.5 days $v$ $57 \cdot 3$ days).

\section{Conclusions}

If efficiency in a surgical service means a high throughput of patients and a low rate of cancellation we have three suggestions.

(1) A surgical service might be provided with fewer beds if patients for elective operations were always admitted on the day of operation and discharged at the earliest opportunity and if elderly patients with chronic illness were transferred to other care. The potential for such economy is, however, only $10 \%$ of the average number of beds occupied ( 3.5 of 34.5 in our study).

(2) Numbiers of beds should not be decreased further: physical removal of beds runs the risk that fluctuations in the need for beds can be accommodated only by cancelling elective admissions.

(3) If all surgeons in a district were to increase their throughput the overall cost of health care would be increased and there would be a risk of bankrupting the district health authority. A new system of funding should be set up to encourage efficient surgical units with short waiting lists.

We thank the many house surgeons who entered the dataRichard Baker, Mike Catchpole, Sam Chong, Elizabeth Clifford, Iona Cobb, Paula Domizio, Ellie Dow, Claire Etherington, Paul Eyers, Emily Finch, Susan Fish, Alison Grant, Andrea Hughes, Roy Love, Gisella Martinez, Chris Mattock, Marek Miller, Leonie Penna, Melanie Robson, Eileen Rosenfelder, Emma Rowley-Conwy, Andrew Sadler, Alison Seidlin, Peter Stone, Richard Sturgess, John Winchester, Chris Yerbury-and Miss J Oyston for secretarial help.

(Accepted 16 August 1988)

\title{
Ambulatory pH monitoring of gastro-oesophageal reflux in "morning dipper" asthmatics
}

\author{
Robyn A Nagel, Paul Brown, Warren H Perks, R S E Wilson, Graeme D Kerr
}

\begin{abstract}
A causal relation between gastro-oesophageal reflux and nocturnal asthma has been postulated. Forty four adult asthmatics underwent ambulatory monitoring of their oesophageal pH over 24 hours to find out if there was such a relation. Of these 21 showed significant "morning dipping" in which the peak expiratory flow falls during the night.

Asthmatics with morning dipping had a history of nocturnal wheeze and a higher incidence of reflux symptoms, but measurement of oesophageal pH showed no significant difference in the amount or pattern of reflux when compared with "nondippers."

Overall, 15 asthmatics had gastro-oesophageal reflux, and these participated in a randomised, double blind crossover trial of ranitidine versus placebo. No significant difference was found in the peak expiratory flow rates or subjective evaluation of well being of the patients.
\end{abstract}

\section{Introduction}

Gastro-oesophageal reflux has been reported to be more common in asthmatics ${ }^{1}$ and has been postulated to cause worsening of asthma, particularly nocturnal wheezing. ${ }^{2}$ The cause of this is unknown but microaspiration of the contents of the stomach might be one possible mechanism, and improvement of asthma has been reported after surgical repair of hiatus hernia. ${ }^{3}$ Another possible mechanism is that the presence of acid in the oesophagus may stimulate vagal nerve endings which can cause reflex bronchoconstriction. ${ }^{4}$

This study was performed to find out if there was a difference in the degree of gastro-oesophageal reflux

TABLE I-Asthma scores as defined by Goodall et a ${ }^{\circ}$

\begin{tabular}{lll}
\hline Asthma score & Daytime & Night time \\
\hline 0 & No wheeze & No wheeze \\
1 & Wheeze 1-2 hours & Slept well, slight wheeze \\
2 & Wheeze most of the day & Woke 2-3 times wheezing \\
3 & Wheeze all day & Bad night, much wheeze \\
\hline
\end{tabular}

TABLE II-Gastro-oesophageal reflux scores as defined by Goodall et $a l^{6}$

\begin{tabular}{lll}
\hline $\begin{array}{l}\text { Gastro-oesophageal } \\
\text { reflux score }\end{array}$ & Heartburn & Regurgitation \\
\hline 0 & $\begin{array}{l}\text { None } \\
\text { Occasional }\end{array}$ & $\begin{array}{l}\text { None } \\
\text { Occasional (on straining or } \\
\text { posture change) } \\
1\end{array}$ \\
2 & $\begin{array}{l}\text { Needing antacids or } \\
\text { medical advice } \\
\text { Constant (interfering } \\
\text { with daily activities) }\end{array}$ & $\begin{array}{l}\text { Occurrence of pulmonary } \\
\text { aspiration }\end{array}$ \\
3 & &
\end{tabular}

between asthmatics with "morning dipping," in which the peak expiratory flow rate falls during the night, and asthmatics in which this does not occur ("nondippers"). We also gave ranitidine and placebo to asthmatics with gastro-oesophageal reflux to see whether they would benefit from reduction of acidity in the stomach.

\section{Patients and methods}

Forty four adult asthmatics attending the respiratory clinic agreed to participate in the study. All patients showed a greater than $25 \%$ increase in peak expiratory flow rate or forced expiratory volume in one second after treatment with bronchodilators. No patient had had gastric or oesophageal operations. One patient who had been prescribed ranitidine for gastrooesophageal reflux stopped taking the drug for the duration of the study. All patients continued their usual medications for asthma. We recorded the weight of each patient as percentage deviation from the population mean, ${ }^{5}$ taking account of age, sex, and height. A patient was considered to have a history of reflux if symptoms occurred at least once every six weeks.

The patients kept a diary for six days and returned to hospital on day 7 for ambulatory monitoring of their oesophageal $\mathrm{pH}$. They recorded type, dose, and timing of drugs as well as their asthma and reflux scores ${ }^{6}$ for day and night (tables I and II). To determine the peak expiratory flow rate of each patient the best of three
Correspondence to:

Dr R Nagel, Flat 14

Surbiton Court, Surbiton,

Surrey. 
blows on a Wright's peak flow meter was recorded just after each patient rose in the morning, one hour later, and just before the patient retired at night. The early morning and evening measurements were made before drugs due at those times were taken. Morning dipping was defined as a greater than $20 \%$ fall in peak expiratory flow rate from evening to morning taken from the mean of values over seven days.

To monitor the oesophageal $\mathrm{pH}$ of the patients we positioned a $\mathrm{pH}$ probe $5 \mathrm{~cm}$ above the lower oesophageal sphincter using a two channel pressure transducer which was mounted on a catheter (Gaeltec) and passed nasally. Eight subjects were unable to use this and the probe was positioned according to changes in $\mathrm{pH}$. A monopolar antimony $\mathrm{pH}$ electrode (Synectics) that was calibrated in buffers of $\mathrm{pH} 1$ and $\mathrm{pH} 7$ was used. The information collected on the digital recording device was analysed by the Synectics "Esophagram" software program (Esophagram

TABLE III-Characteristics of morning-dipping and non-dipping asthmatics

\begin{tabular}{|c|c|c|}
\hline & Morning dippers & s Non-dippers \\
\hline Total No of patients & $21(8 \mathrm{men})^{\star}$ & $23(14 \mathrm{men})^{\star}$ \\
\hline Mean ((SD) (range)) age & $40((14)(20-64))$ & $44((15)(22-63))$ \\
\hline Weight (\% deviation from ideal) & $+6^{\star}$ & $-3^{\star}$ \\
\hline $\begin{array}{l}\text { No }(\%) \text { of patients with reflux } \\
\text { symptoms }\end{array}$ & $13+(62)$ & $7+(30)$ \\
\hline $\begin{array}{l}\text { No }(\%) \text { of patients with regular } \\
\text { nocturnal wheeze causing } \\
\text { awakening }\end{array}$ & $16+(76)$ & $10+(43)$ \\
\hline $\begin{array}{l}\text { Median percentage time } \mathrm{pH}<4 \\
\text { Maximum } \% \text { time with reflux: }\end{array}$ & $2 \cdot 1^{\star}$ & $2 \cdot 3^{\star}$ \\
\hline Day & 17 & 19 \\
\hline Night & 4 & 4 \\
\hline $\begin{array}{l}\text { No }(\text { SD) episodes reflux }>5 \\
\text { minutes }\end{array}$ & $2 \cdot 7(4 \cdot 2)^{\star}$ & $3 \cdot 4(6 \cdot 3)^{\star}$ \\
\hline $\begin{array}{l}\text { No (\%) asthmatics with gastro- } \\
\text { oesophageal reflux }\end{array}$ & $7(30)^{\star}$ & $8(35)^{\star}$ \\
\hline
\end{tabular}

$\star$ No significant difference between morning dippers and non-dippers. t0.01<p<0.05 for morning dippers compared with non-dippers.

TABLE IV-Characteristics of 15 asthmatics with gastro-oesophagea reflux taking part in a crossover study comparing ranitidine with placebo

\begin{tabular}{lll}
\hline & Morning dippers & Non-dippers \\
\hline $\begin{array}{l}\text { No of patients } \\
\text { No of patients with night time }\end{array}$ & $7(4 \mathrm{men})$ & $8(7 \mathrm{men})$ \\
$\quad$ wheeze causing awakening & 5 & 2 \\
$\begin{array}{l}\text { No of patients with symptoms of } \\
\quad \text { reflux }\end{array}$ & 4 & 3 \\
$\begin{array}{l}\text { Median (range) percentage of time } \\
\quad \text { with pH<4 }\end{array}$ & $15 \cdot 5(6 \cdot 6-43 \cdot 0)$ & $24 \cdot 0(4 \cdot 2-38 \cdot 0)$ \\
$\begin{array}{l}\text { Maximum \% time with reflux: } \\
\quad \text { Day }\end{array}$ & 5 & \\
$\quad$ Night & 2 & 6 \\
$\begin{array}{l}\text { Mean No of different drugs' } \\
\text { patient }\end{array}$ & $2 \cdot 9$ & $3 \cdot 0$ \\
& &
\end{tabular}

TABLE $\mathrm{v}-$ Results of crossover trial in 15 asthmatics with gastro-oesophageal reflux comparing treatment with ranitidine and placebo



^No significant difference.

†No significant difference.
959803). We recorded the number of episodes of reflux (oesophageal $\mathrm{pH}<4$ ) which lasted longer than five minutes, and the percentage of time with oesophageal $\mathrm{pH}<4$ during 24 hours. The pattern of reflux was defined as the period during which the maximum percentage of time with $\mathrm{pH}<4$ occurred. Time spent lying in bed at night was night time and the remainder daytime.

Fifteen asthmatics who had gastro-oesophageal reflux proceeded to a double blind, randomised, crossover study comparing ranitidine $300 \mathrm{mg}$ at $9 \mathrm{pm}$ and $150 \mathrm{mg}$ at 9 am with placebo for seven days with an interval of three days between drugs. The patients kept diaries as before and returned unused tablets to be counted. The protocol was approved by the Shropshire health authority's ethical committee.

Gastro-oesophageal reflux was defined as either a recording below $\mathrm{pH} 4$ for more than $4 \cdot 2 \%$ of the time or more than three episodes of reflux lasting longer than five minutes. ${ }^{7}$ Non-parametric data were assessed statistically by a two sample Wilcoxon test. Parametric data were analysed by $\chi^{2}$ and two sample $t$ tests. Paired data were compared by a $t$ test for paired differences.

\section{Results}

Of the 44 asthmatics, 21 showed morning dipping in peak expiratory flow rate (table III). The overall incidence of gastro-oesophageal reflux was $34 \%$. There were more women morning dippers than non-dippers but the difference was not significant. There was a trend for morning dippers to weigh more than nondippers but this also was not significant. Morning dippers had significantly more symptoms of reflux and episodes of nocturnal awakening with wheeze. There was no significant difference between morning dippers and non-dippers in the percentage time with oesophageal $\mathrm{pH}<4$, the number of episodes of reflux lasting longer than five minutes, or the number of subjects found to have reflux. The pattern of reflux was similar for both.

Table IV shows the details of the 15 subjects with gastro-oesophageal reflux who entered the second part of the trial. One was withdrawn after developing severe headache on ranitidine. Seven subjects had a history of regular nocturnal wheezing; five of these were morning dippers. Eight subjects suffered no symptoms from the reflux.

The results of the treatment with ranitidine and placebo are shown in table $V$. There was no significant difference in the evening or morning peak expiratory flow rate or the doses of medications for asthma each subject took daily between the week taking ranitidine and the week taking placebo. Asthma scores improved in three patients on ranitidine, but deteriorated in five. No patient had worse symptoms of reflux when taking ranitidine and three improved.

\section{Discussion}

Investigation of a possible relation between gastrooesophageal reflux and asthma has been hindered by difficulties in diagnosing reflux. Ambulatory monitoring of the oesophageal $\mathrm{pH}$ has been shown to be the most accurate test for detecting acid reflux.$^{89}$ Comparison with early studies is difficult as many of them relied on the presence of a hiatal hernia or reflux stress tests to diagnose pathological reflux. ${ }^{10}$

The incidence of gastro-oesophageal reflux in our asthmatic patients was $34 \%$, which is lower than that recorded previously by $\mathrm{pH}$ monitoring though these studies were in children." Whether the incidence of reflux is increased in asthmatics remains controversial, but three separate controlled trials ${ }^{12-14}$ all found no significant difference between controls and asthmatics. 
We found no difference in the incidence of reflux in asthmatics with predominantly nocturnal symptoms and those without these symptoms. The trial of Berquist et al was interesting in that it showed no influence on gastro-oesophageal reflux from theophylline or orciprenaline sulphate, ${ }^{12}$ both of which decrease the lower oesophageal sphincter pressure. Individual cases of microaspiration have been reported, ${ }^{15} 16$ but in a trial of 10 asthmatics with symptoms of gastro-oesophageal reflux no aspiration was shown, suggesting that this mechanism is uncommon at least in this group. ${ }^{17}$

Although the incidence of reflux dnes not appear to be increased in asthmatic patients, they may be more sensitive to stimulus caused by reflux. This hypothesis is difficult to prove, especially because trial numbers were small. One hypothesis is that the presence of acid in the oesophagus may stimulate vagal nerve endings that cause reflex bronchoconstriction. Acid infused into the oesophaguses of anaesthetised dogs resulted in a rise in resistance to respiration which was abolished with vagotomy. ${ }^{4}$ Acid perfusion of the oesophagus in 15 asthmatics, however, showed changes only in airway resistance without any significant changes in forced expiratory volume in 1 second or peak expiratory flow rate. ${ }^{18}$ Respiratory sensitivity to inhaled histamine increased after acid challenge in asthmatic children but there were no changes in baseline peak flow rate. ${ }^{19}$

Goodall treated 18 nocturnal wheezers symptomatic for gastro-oesophageal reflux with six weeks of cimetidine $1 \mathrm{~g}$ daily and placebo. A significant rise in evening peak expiratory flow rate of $7 \%$ after treatment with cimetidine was associated with subjective improvement in the symptoms of asthma. ${ }^{6}$ Our study was similar to Goodall's but we used measurement of oesophageal $\mathrm{pH}$ to find out which patients had acid reflux, and we used ranitidine, which has been shown to be effective for gastro-oesophageal reflux. ${ }^{20}$ Although there are reports of histamine type $2\left(\mathrm{H}_{2}\right)$ receptors with minor activity in the lung ${ }^{21}$ and that ranitidine has some cholinomimetic activity, ${ }^{22}$ there have been no clinical reports of ranitidine causing bronchoconstriction without a generalised anaphylactic reaction. We did not find any improvement in well being or peak expiratory flow rate in patients with reflux treated with ranitidine.

We conclude that although morning dipping asthmatics had a higher incidence of reflux symptoms, no difference was found in the incidence of gastro- oesophageal reflux compared with non-dipping asthmatics. Furthermore, no changes in respiratory function or clinical improvement in asthma were seen when subjects with reflux were treated with an $\mathrm{H}_{2}$ antagonist. These findings suggest that acid reflux does not contribute significantly to nocturnal wheeze and that treatment with the $\mathrm{H}_{2}$ antagonist ranitidine is not helpful in preventing nocturnal worsening of asthma.

We thank Mr Richard Steventon, Sister Di Campbell, Miss Wendy Humphreys, and Miss Sue Phillips for their help.

1 Mayse. Intrinsic asthma in adults, association with gastro-oesophageal reflux. fAMA 1976;236:2626-8.

2 Anonymous. Gastric asthma. Lancet 1985;ii:1399-1400.

3 Overhold $\mathrm{RH}$, Ashraf $M M$. Oesophageal reflux as a trigger in asthma. $N Y$ State f Med 1966;ii:3030-2.

4 Mansfield L, Hameister HH, Spaulding HS, Smith NJ, Glab N. The role of the vagus in airway narrowing caused by intra-oesophageal hydrochloric acid provocation and oesophageal distension. Ann Allergy 1981;47:431-4.

5 Passmore R, Eastwood MA. Human nutrition and dietetics. 8th ed. London: Churchill Livingstone, 1986:521.

6 Goodall RJ, Earis JE, Cooper DN, Bernstein A, Temple JG. Relationship between asthma and gastro-oesophageal reflux. Thorax 1981;36:116-21.

7 Demeester TR, Wang CI, Wernly JA, et al. Techniques, indications and clinical use of 24 hour oesophageal $\mathrm{pH}$ monitoring. I Cardiovasc Surg (Torino) 1980;79:656-70.

8 Sranciu C, Hoare RC, Bennett JR. Correlation between manometric and $\mathrm{pH}$ tests for gastro-oesophageal reflux. Gut 1977;18:536-40.

9 Schleisinger PK, Donahue PE, Schmidt D, Layden TJ. Intra-oesophageal pH monitoring in the hospital setting. Gastroenterology 1985;89:797-804

10 Shapiro GC, Christie DL. Gastro-oesophageal reflux in steroid-dependent asthmatic youths. Pediatrics 1979;63:207-11.

11 Martin ME, Grunstein MM, Larsen GL. The relationship of gastrooesophageal reflux to nocturnal wheezing in children with asthma. Ann Allergy 1982;49:318-22.

12 Berquits WE, Rachelefsky GS, Rowshan N, Siegel S, Katz R, Welch M. Quantitative gastro-oesophageal reflux and pulmonary function in asthmatic children and normal adults receiving placebo, theophylline and metaproterenol sulfate therapy. $\mathcal{F}$ Allergy Clin Immunol 1984;73:253-8.

13 Perpina M, Ponce J, Marco V, Belloch E, Mirables M, Berenguer J. The prevalence of asymptomatic gastro-oesophageal reflux in asthmatic and nonprevalence of asymptomatic gastro-oesophageal reflux in
asthmatic individuals. Eur $\mathcal{I}$ Respir Dis 1983;64:582-7.

14 Hughes DM, Spier S, Rivlin J, Levinson H. Gastro-oesophageal reflux during ughes DM, Spier S, Rivlin J, Levinson H. Gastro-oesop
sleep in asthmatic patients. $\mathcal{F}$ Pediatr 1983;102:666-71.

15 Greyson ND, Reid RH, Lui YC, Thomas P. Radionucleide assessment in nocturnal asthma. Clin Nucl Med 1982;7:318-9.

16 Bengtsson U, Sandberg N, Bake B, et al. Gastro-oesophageal reflux and nighttime asthma. Lancet 1985; i: 1501 .

17 Ghaed N, Stein M. Assessment of a technique for scintographic monitoring of pulmonary aspiration of gastric contents in asthmatics with gastrooesophageal reflux. Ann Allergy 1982;284:306-8.

18 Mansfield LE, Stein MR. Gastro-oesophageal reflux and asthma: a possible mechanism. Ann Allergy 1979;63:207-11.

19 Wilson N, Charette L, Thompson AG, Silverman M. Gastro-oesophageal reflux and childhood asthma. Thorax 1985;40:592-7.

20 Wesdorp CE, Dekker W, Klinkenberg-Knol EC. Treatment of reflux oesophagitis with ranitidine. Gut 1983;24:921-4.

21 Chakrin LW, Krell RD. Histamine receptors in the respiratory system. In: Torsoli A, Luccheli PE, Brimblecombe $\mathrm{RW}$, eds. $\mathrm{H}_{2}$ receptor antagonists in peptic ulcer disease and progress in histamine research. (European symposium peptic ulcer disease and progress in histamine research. (European
on $\mathrm{H}_{2}$ receptors.) Amsterdam: Excerpta Medica, 1979:338-46.

22 Cohen $\mathrm{S}$ (ed). Update: $\mathrm{H}_{2}$ receptor antagonists. London: Biomedical Information Corporation, 1983:9-19 (International symposium of the Royal Society of Medicine)

(Accepted 8 September 1988)
When the Bill for Creating Life Peerages was under discussion in the Upper House, Lord Granville made some happy remarks about the aged friends around him. "As the sun smiled agreeably upon the Government side of the House he was glad to see that two or three members retained their 'dark and curly locks,' but he was sorry to say that the sun also revealed a good many heads not only tinged with grey, but even more decidedly white, as well as some which showed almost an absence of locks altogether. It might even be said that their lordships constituted not a middle-aged but an aged assembly. But the category of life peers proposed by the noble marquis would add a very considerable percentage to the noble lords who, like himself, were so aged as to be utterly useless. $\mathrm{He}$ thought this was a very serious objection." Should grey heads be the main depositories of governing power? The question has extended social bearings, and is worth considering when the constitution of the House of Peers, the creation of County Councils, and the government of Universities and Medical Corporations are attracting much attention. There are advantages and disadvantages in recruiting a governing body largely from among men of advanced years, full of ripe experience. Such men have a wide and extended acquaintance with society, and much freedom from the minor views of personal interest, which enables them to look to public duty as well as to the advantage of their corporate body; they have fixed principles and acquaintance with custom and precedence, they add weight, respectability and continuity of action to the proceedings in which they take part - further they sometimes add to the wealth of the body to which they belong by kindly and well bestowed bequests. On the other hand, younger men add other characters to the governing assembly; they confer the power of greater labour, the capacity to analyse proposals and collect evidence; they are a power for the self-reform which is so necessary in any corporate body that has a long life and important interests to guard for others. The younger men give a "plasticity" to a council, so that it becomes impressed and moulded by varying circumstances in accord with the interest and needs of those who are represented; they also serve to protect the body to which they belong from a great danger to which it is exposed when entirely composed of older men - the danger of being governed by its own officers rather than by the mental power of the whole body and that of each individual member.

(British Medical Fournal 1888;ii:241) 